\title{
Overview of the Enforcement of the Market Abuse Prohibition in the United Kingdom
}

\author{
Howard Chitimira \\ LLB LLM LLD \\ Lecturer, Faculty of Law, North-West University \\ Email:Howard.Chitimira@nwu.ac.za or tafarachitimira@gmail.com
}

Doi:10.5901/mjss.2014.v5n20p272

\begin{abstract}
Like several other countries, the United Kingdom has a regulatory and enforcement framework in place to combat insider trading, as well as other forms of market manipulation practices. Put differently, a robust and relatively effective anti-market abuse regulatory and enforcement framework is in place in the United Kingdom. Consequently, and where appropriate, the relevant enforcement approaches of the United Kingdom's market abuse regime will be compared with similar approaches that are provided for in the South African anti-market abuse framework. This is primarily done to, inter alia, isolate possible and applicable anti-market abuse enforcement approaches from the United Kingdom's market abuse regime that could be adopted and/or integrated in the South African anti-market abuse enforcement framework. In relation to this, the role of the Financial Services Authority will be analysed first. Secondly, a similar analysis will be carried out in respect of the courts. Thirdly, the role of the self-regulatory organisations will be discussed. Lastly, final concluding remarks will be provided.
\end{abstract}

Keywords: market abuse, enforcement, United Kingdom, framework, South Africa.

\section{Introduction}

Like several other countries, the United Kingdom (the UK) has a regulatory and enforcement framework in place to combat insider trading, ${ }^{1}$ as well as other forms of market manipulation ${ }^{2}$ practices. ${ }^{3}$ Put differently, a robust and relatively effective anti-market abuse regulatory and enforcement framework is in place in the UK. Consequently, and where appropriate, the relevant enforcement approaches of the UK's market abuse regime will be compared with similar approaches that are provided for in the South African anti-market abuse framework. ${ }^{4}$ This is primarily done to, inter alia, isolate possible and applicable anti-market abuse enforcement approaches from the UK's market abuse regime 5 that could be adopted and/or integrated in the South African anti-market abuse enforcement framework. In relation to this, the role of the Financial Services Authority (the FSA) will be analysed first. Secondly, a similar analysis will be carried out in respect of the courts. Thirdly, the role of the self-regulatory organisations will be discussed. Lastly, final concluding

\footnotetext{
1 See the Criminal Justice Act 1993 (c 36), hereinafter referred to as the Criminal Justice Act.

2 See the Financial Services and Markets Act 2000 (c 8), hereinafter referred to as the Financial Services and Markets Act. Also see Avgouleas The Mechanics and Regulation of Market Abuse: A Legal and Economic Analysis (2005) 307. For further related analysis on the enforcement of the market abuse ban in other countries, see Bhattacharya \& Daouk "The World Price of Insider Trading" 2002 Journal of Finance 75 75-108; Lyon \& Du Plessis The Law of Insider Trading in Australia (2005) 159-168.

${ }^{3}$ Notably, both insider trading and market manipulation practices are referred to as "market abuse" in this article.

4 For further related analysis, see ss 78; 80; 81 \& 82 of the Financial Markets Act 19 of 2012, hereinafter referred to as the Financial Markets Act: Chitimira A Comparative Analysis of the Enforcement of Market Abuse Provisions (2012) LLD thesis, Nelson Mandela Metropolitan University, 319-332. Also see Botha "Control of Insider Trading in South Africa: A Comparative Analysis" 1991 SA Merc LJ 1 1-18; Botha "Increased Maximum Fine for Insider Trading: A Realistic and Effective Deterrent?" 1990 SALJ 504-508; Chitimira The Regulation of Insider Trading in South Africa: A Roadmap for an Effective, Competitive and Adequate Regulatory Statutory Framework (2008) LLM dissertation, University of Fort Hare, 41-72; Loubser "Insider Trading and other Market Abuses (Including the Effective Management of Price-sensitive Information)" in the Insider Trading Booklet final draft, (2006) 18-20; $24-27$ <http://www.jse.co.za/public/insider/JSEbooklet.pdfs (accessed 03-03-2014); the Johannesburg Stock Exchange Limited (the JSE) "Insider Trading and other Market Abuses (Including the Effective Management of Price-sensitive Information)" in the Insider Trading Booklet, (2013) 1-26 <http://www.jse.co.za/Libraries/JSE_Regulatory_Environment_Insider_Trading/InsiderTrading_Booklet.sflb.ashx> (accessed 03-03-2014); Van Deventer "Anti-Market_Abuse Legislation in South Africa" (10-06-2008) 1-5 <http://www.fsb.co.za/public/marketabuse/FSBReport.pdfs (accessed 05-05-2013); Myburgh \& Davis "The Impact of South Africa's Insider Trading Regime: A Report for the Financial Services Board" (25-03-2004) 8-33 <http://www.genesis-analytics.com/public/FSBReport.pdfs (accessed 09-02-2013); Chanetsa "Insider Trading is Notoriously Hard to Prosecute" Business Report 26 April 2004; Pretorius and Another v Natal South Sea Investment Trust 19653 SA 410 (W), were the courts failed to convict the suspected insider trading offenders; Blincoe "Datatec Directors Pay Up on Insider Trading Charges" (2001) <http://www.theregister.co.uk/2001/05/23/datatec_directors_pay_up/> (accessed 03-03-2014), where two Datatec directors, Jens Montanana and Robin Rindel were reportedly fined about R1 million each for insider trading by the Financial Services Board (the FSB); Barron "Greg Draws a Blank in Belfort Parallel" (2014) <http://www.timeslive.co.za/Feeds/2014/02/02/greg-draws-a-blank-in-belfort-parallel> (accessed 03-03-2014), where Greg Blank was reportedly sentenced to eight years imprisonment for stock market-related fraud and front running in 1992; Osode "The new South African Insider Trading Act: Sound law reform or legislative overkill?" 2000 Journal of African Law 239 239-263; Jooste "A critique of the insider trading provisions of the 2004 Securities Services Act" 2006 SALJ 437 441-460; Beuthin \& Luiz Beuthin's Basic Company Law (2000) 235-238; Luiz "Market Abuse and the Enforcement Committee" 2011 SA Merc LJ 151-172; Luiz "Insider Trading Regulation - If at First You Don't Succeed..." 1999 SA Merc LJ 136 136-151 \& Henning \& Du Toit "The Regulation of False Trading, Market Manipulation and Insider Trading" 2000 Journal for Juridical Science 155 155-165, for historical analysis of the regulation and enforcement of the market abuse prohibition in South Africa.

${ }^{5}$ Barnes Stock Market Efficiency, Insider Dealing and Market Abuse (2009) 125.
} 
remarks will be provided.

\section{Detection, Prosecution and Enforcement of the Market Abuse Prohibition}

\subsection{The Role of the Financial Services Authority}

The FSA was established as the main single body which administers an integrated regulatory system for all the financial services and markets in the UK. ${ }^{6}$ This further suggests that the FSA has the main responsibility of administering and enforcing the prohibition on market abuse in the UK. ${ }^{7}$

Although there are a number of other regulatory bodies, the FSA has the sole responsibility and powers to police the enforcement of the market abuse prohibition in the UK. These powers include to investigate or refer a matter to its Regulatory Decisions Committee (the RDC); impose unlimited monetary penalties; make a public statement that a person has engaged in market abuse, and to apply to the courts for an injunction to claim restitution or restrain continued market abuse. ${ }^{8}$ The FSA may further make market abuse rules and determine the general policy and principles to govern the performance of particular functions in the relevant financial markets. ${ }^{9}$

In order to enhance its enforcement, the FSA is divided into several divisions such as the Supervision, Markets and Enforcement Divisions. ${ }^{10}$ The Supervision Division's sub-divisions within the FSA that can make referrals to the Enforcement Division consist of major retail groups, retail firms, contact revenue and information management groups and the financial markets. ${ }^{11}$ The FSA is further equipped with extensive interrogatory and investigatory powers which it may objectively exercise against any persons who violate the market abuse provisions. ${ }^{12}$ It may, for example, by written notice require an authorised person to provide specific information and other specified documents relevant to an ongoing investigation. ${ }^{13}$ Moreover, the FSA may appoint additional persons as investigators of certain market abuse cases. ${ }^{14}$

The FSA can also act as a quasi-judicial and quasi-legislative regulatory body. Consequently, the FSA may seek judicial and quasi-judicial remedies from the High Courts, namely issuer freezing orders or restitution orders against market abuse offenders, in order to stop a particular market abuse conduct. Moreover, the FSA's legislative role comprises, inter alia, powers to promulgate relevant rules regarding market abuse to guide all market participants in the UK. ${ }^{15}$ In light of this, the FSA issued a Code of Market Conduct which provides guidance regarding conduct that amounts to market abuse in the UK. ${ }^{16}$

In addition, the Code of Market Conduct outlines in more detail the standards required of all participants in the UK's financial markets. It broadly defines three categories of conduct that amount to market abuse, namely misuse of information, dissemination of false or misleading information and market distortion. Misuse of information is defined to involve behaviour (action or inaction) that is based on information which is not generally available but which would be relevant to an investor's dealings in a particular investment and which is ordinarily disclosed to the market. Dissemination of false or misleading information is defined to involve behaviour that gives rise to or that is likely to give rise to false or misleading impression as to the supply or demand, price or value of an investment. ${ }^{17}$ Distortion of the market is defined in the Code of Market Conduct to include conduct that interferes with the normal process of supply and demand and which manipulates the market price of an investment. ${ }^{18}$

Information gathering and relying on competent companies or skilled persons is another tool that is used by the FSA. This enables the FSA to gather information from both authorised persons and in certain instances, from nonregulated persons to prevent possible market abuse activity from occurring. Specifically, this is done by the use of skilled

\footnotetext{
${ }^{6}$ The FSA was introduced on 27 October 1997 as the main regulatory body which replaced all earlier and similar regulatory agencies in the UK. See Blair \& Walker Financial Services Law (2006) 3.

7 This is the so-called single regulator model which in this context entails that only one regulatory body (the FSA) has the main authority to supervise the regulation and enforcement of the market abuse ban in the UK. It is, however, not the purpose of this sub-heading to discuss all the merits and demerits of this so-called single regulator model.

${ }^{8}$ S 2(4) of the Financial Services and Markets Act which stipulates the general functions of the FSA. Also see Barnes Stock Market Efficiency, Insider Dealing 138-139.

9 Ss 138 to 158. For further analysis, check Blair \& Walker Financial Services Law 14-17.

${ }^{10}$ Swan Market Abuse Regulation (2006) 88.

11 Therefore, supervisors are responsible for isolating market abuse cases in order to submit them to the Enforcement Division or the Crown Prosecution Services (the CPS) or the Director of Public Prosecutions (the DPP) for further investigation and prosecution.

${ }^{12}$ Ss 165 to 169 \& s 284 of the Financial Services and Markets Act.

${ }_{13}$ S 165(1); (2) \& (3) of the Financial Services and Markets Act; also see further Avgouleas The Mechanics and Regulation of Market Abuse $368-370$.

14 Ss 97; 167; 168; 173 \& 175 of the Financial Services and Markets Act. In addition, see Rider, Alexander, Linklater \& Bazley Market Abuse and Insider Dealing (2009) 189-190.

$15 \mathrm{~S} 119$ read with s 122 of the Financial Services and Markets Act.

${ }^{16}$ See the FSA Handbook (Code of Market Conduct) released on 19 July 2001.

17 The FSA has to date utilised the Internet bulletin boards to disclose relevant information relating to a number of qualifying investments. This is aimed at preventing market manipulation activities like the so-called pump and dump schemes which often prejudice innocent investors.

${ }^{18}$ For example, when a person purchases large amounts of a particular share at or near the end of the day to mislead other investors.
} 
person's reports to identify or track market abuse practices in the UK's financial markets. ${ }^{19}$

The FSA may impose disciplinary sanctions on persons who commit market abuse offences. Such disciplinary sanctions comprise injunctions to disgorge the profits gained or stop certain market abuse activity, issuing warning notices, cancelling or withdrawing of Part IV permission, and prohibiting certain individuals from carrying out their functions that relate to regulated activities. ${ }^{20}$

With regard to detection, the FSA in conjunction with the London Stock Exchange (the LSE) relies on the Stock Exchange Automated Quotation market marking system to detect all possible market abuse activities in the relevant financial markets. ${ }^{21}$ Moreover, all listed UK equities and other investments listed on a subsidiary market known as the Alternative Investment Market could further rely on the Stock Exchange Alternative Trading System or Stock Exchange Automated Quotation or another trading system known as the Stock Exchange Alternative Trading System Plus to detect and curb market abuse practices.

In order to combat cross-border market abuse practices, the FSA has brokered some co-operation with similar bodies in other jurisdictions. It has, for instance, signed various Memoranda of Understanding with other regulatory bodies like the United States Securities and Exchange Commission (the SEC), the Commodity Futures Trading Commission (the CFTC) and the International Organisation of Securities Commissions (the IOSCO). ${ }^{22}$

As indicated above, it is evident that the FSA plays a key role in the enforcement of the securities and market abuse provisions in the UK. For instance, notwithstanding the fact that the FSA is primarily responsible for the enforcement of the civil remedy for market abuse, it further oversees the enforcement of other securities laws in the UK.

Moreover, although a few criminal cases of market manipulation and insider trading have been successfully prosecuted since the inception of the UK's market abuse regime in 1986, relatively more prosecutions of such cases have been obtained, especially after 2001 when the FSA took over from the Department of Trade and Industry (the DTI). ${ }^{23}$ For instance, about five criminal cases of market abuse have so far been successfully prosecuted by the FSA. ${ }^{24}$ Additionally, in the Rigby and Bailey scandal, Carl Rigby and Gareth Bailey were convicted for making a reckless statement, promise or forecast which was deceptive and misleading and sentenced to eighteen months imprisonment each. ${ }^{25}$ They were further convicted of contravening the disclosure provisions of the Financial Services and Markets $\mathrm{Act}^{26}$ and sentenced to a two year jail term each. In the Hipwel and Bhoyrul scandal, Hipwell was jailed for six months; Shepherd was also jailed for three months while Bhoyrul was sentenced to 180 hours of community service for market abuse and conspiracy to commit market abuse on 17 December 2005. ${ }^{27}$

In contrast to the few successful prosecutions achieved in the criminal cases of market abuse, ${ }^{28}$ the FSA has to date obtained relatively more settlements in civil cases involving market abuse, especially after enactment of the enactment of the Financial Services and Markets Act. ${ }^{29}$ About twelve cases of market abuse offences which were committed during the period between April 2004 and March 2007 have so far been settled with the FSA. ${ }^{30}$ Moreover, about five cases which constituted a breach of the FSA's Listing Rules were settled with the FSA during the same period. ${ }^{31}$

The FSA has, in the wake of the early 1980s market abuse scandals such as the Guinness-Distillers ${ }^{32}$ and the Blue

\footnotetext{
19 The FSA is manned by about 2500 to 3000 competent persons (staff). This could further imply that that the Enforcement Division and other Divisions of the FSA have competent and skilled persons. See generally Rider, Alexander, Linklater \& Bazley Market Abuse and Insider Dealing 190-195 \& Blair \& Walker Financial Services Law 34-35.

${ }^{20}$ Rider, Alexander, Linklater \& Bazley Market Abuse and Insider Dealing 203 \& 225-229.

${ }^{21}$ Barnes Stock Market Efficiency, Insider Dealing 19.

22 In 2008, the FSA co-chaired the IOSCO task force on other unregulated entities and hedge funds in order to examine alternative regulatory approaches that mitigate the risk associated with their illicit market abuse practices. Generally see the CFTC \& the FSA's Memorandum of Understanding on Consultation, Cooperation and the Exchange of Information Related to Market Oversight (2006) <http://www.fsa.gov.uk/pubs/mou/cftc.pd> (accessed 27-01-2014) \& see further the FSA "FSA Signs Regulatory Cooperation Agreement with the CFTC" (20-11-2006) http://www.fsa.gov.uk/pages/Library/Communication/PR/2006/118.shtml> (accessed 27-01-2014). Also see the CFTC \& the SEC "A Joint Report of the SEC and the CFTC on Harmonization of Regulation" Report 16 October 2009 81; also see Memoranda of Understanding (MOUs) which can be accessed at <http://www.hm-treasury.gov.uk/documents/financial_services/regulating_financial_services/fin_rfs_mou.cfm> (accessed 26-01-2014) \& generally see the IOSCO Technical Committee Working Party 4 on Principles for Memorandum of Understanding, XVI Annual Conference 5 September 1991, which provides the model adopted by the FSA on several financial information sharing agreements (MOUs) that it has entered into with other regulatory bodies since 1992. Blair \& Walker Financial Services Law 35-38.

23 The DTI was previously responsible for enforcing the insider trading prohibition in the UK. It was generally believed that the DTI failed to obtain more convictions in criminal cases involving insider trading in the UK. Precisely, about 15 cases involving 19 individuals were prosecuted for insider trading during the period between 1984 \& 1996 in the UK. However, no convictions were obtained in all these 15 cases. Barnes Stock Market Efficiency, Insider Dealing 161.

${ }^{24}$ See generally Barnes Stock Market Efficiency, Insider Dealing 161.

${ }^{25}$ Barnes Stock Market Efficiency, Insider Dealing 161

${ }^{26}$ S 397(1); also see Barnes Stock Market Efficiency, Insider Dealing 161.

${ }^{27}$ Hipwell, Bhoyrul \& Shepherd allegedly conspired between August 1999 \& February 2000 to buy shares in 44 companies that they later tipped in their column over the Internet. As a result, Hipwell made $£ 41$ 000, Anil Bhoyrul $£ 15000$ \& Terry Shepherd gained about $£ 17$ 000. Barnes Stock Market Efficiency, Insider Dealing $162-164$.

28 Rider, Alexander, Linklater \& Bazley Market Abuse and Insider Dealing 94

${ }^{29}$ See Barnes Stock Market Efficiency, Insider Dealing 174 \& Rider, Alexander, Linklater \& Bazley Market Abuse and Insider Dealing 95.

${ }^{30}$ Eight of these cases involved insider trading; one case constituted improper disclosure of non-public material information; two involved the unlawful dissemination and one constituted distortion and misleading behaviour. Barnes Stock Market Efficiency, Insider Dealing 174

${ }^{31}$ Barnes Stock Market Efficiency, Insider Dealing 174.

32 See related discussion in paragraph 2.2 below; also see Rider, Alexander, Linklater \& Bazley Market Abuse and Insider Dealing 93-94.
} 
Arrow cases, ${ }^{33}$ subsequently introduced stricter measures to curb and prevent the recurrence of similar scandals in all the prescribed markets in the UK. ${ }^{34}$ For example, after a bogus take-over scheme for the shares of Distillers company, the chairman and chief executive officer of Guinness company, Ernest Saunders, financiers and the share support group members namely, Gerald Ronson, Sir Jack Lyons and stock broker Antony Parnes were all convicted of conspiracy, theft and issuing false, misleading or deceptive accounting statements. ${ }^{35}$ Sir Jack Lyons was stripped of his knighthood, Saunders was sentenced to ten years in jail (he, however, served five months of this sentence but it was later halved on appeal due to his pre-senile dementia medical condition) and Gerald Ronson was fined for five million pounds plus a one year jail term. Antony Parnes was sentenced to two and half years imprisonment, but this sentence, however, was later reduced to 21 months on appeal in $1991 .{ }^{36}$ Consequently, the FSA has so far imposed penalties and other appropriate administrative actions against any individuals or companies involved in market abuse activity. For example, in ABN Amro Equities UK case, on 23 April 2003 this company was fined $£ 900000$ for market manipulation. In the same case, Michael Ackers was also fined $£ 70000$ for violation of Principle 3 of the FSA's Listing Requirements which requires companies and the individuals concerned to maintain good corporate standards so as to combat market abuse conduct. ${ }^{37}$ In Shell Transport and Trading and Royal Dutch/Shell Group of companies, ${ }^{38}$ a $£ 17000000$ fine was imposed on the directors as well as other persons who issued false or misleading information to the financial markets contrary to the Listing Rules and the relevant provisions of the Financial Services and Markets Act.

Disciplinary action for a public censure was invoked by the FSA in Marconi plc case. ${ }^{39}$ In this case, the FSA issued a public statement to the effect that Marconi plc had failed to speedily release price-sensitive information regarding a change in its performance expectation to the relevant financial market. ${ }^{40}$ In another case, the FSA found Roberto Casoni (a former equities analyst) guilty for failing to observe the required proper standards of market conduct contrary to its general principles for approved persons. ${ }^{41}$

On the other hand, like the FSA in the UK, ${ }^{42}$ the FSB bears the sole responsibility and function to oversee the enforcement of the securities and market abuse provisions in South Africa. ${ }^{43}$ Nonetheless, unlike the position in the UK, where the Bank of England's regulatory mandate does not include banks because they are regulated by the FSA, ${ }^{44}$ the South African Reserve Bank (not the FSB) oversees the regulation of banks in South Africa. In this regard, the FSA's regulatory powers are broader than those of the FSB. ${ }^{45}$ Nevertheless, like the FSA, ${ }^{46}$ the FSB administers and enforces the civil market abuse provisions in South Africa. ${ }^{47}$ Be that as it may, it is not very clear whether the FSB is also adjudicated by sufficient and competent persons to enhance its cross-border market abuse enforcement efforts in South Africa and elsewhere. ${ }^{48}$ Nonetheless, like the FSA, ${ }^{49}$ the FSB has quasi-legislative (rule-making) powers. ${ }^{50}$ While this is a commendable achievement and must as such be welcomed, it is not quite certain whether the FSB has to date been able to make any such rules or to issue its own adequate Code of Market Abuse Conduct to guide all the relevant market participants on conduct that amounts to market abuse in South Africa. Unlike the FSA's Code of Market Conduct which supplemented and defined market abuse conduct in the UK, ${ }^{51}$ such conduct is merely outlined, mainly in Chapter $\mathrm{X}$ of the Financial Markets Act. ${ }^{2}$ In addition, the FSB may only commence its investigations when it has received some tip-offs

\footnotetext{
${ }^{33}$ Directors and some members of the County NatWest and National Westminster Bank's merchant banking subsidiary were convicted of misleading the market by disguising the failure of their Blue Arrow rights issue in February 1992. However, their convictions were set aside on appeal in August in 1992.

34 Generally see Barnes Stock Market Efficiency, Insider Dealing 148-152.

${ }^{35}$ Barnes Stock Market Efficiency, Insider Dealing 148-152.

${ }^{36}$ Barnes Stock Market Efficiency, Insider Dealing 148-152.

${ }^{37}$ Barnes Stock Market Efficiency, Insider Dealing 164-166.

38 See the FSA Final Notice 2004-08-24; also see Rider, Alexander, Linklater \& Bazley Market Abuse and Insider Dealing 215.

${ }^{39}$ Generally see Barnes Stock Market Efficiency, Insider Dealing 164-165; also see other similar cases such as the Financial Services Authority $v$ (1) Sean Fradley (t/a Top Bet Placement Services) (2) Gary Woodward [2004] EWHC 3008 (Ch), where the FSA successfully obtained injunctions against the market abuse offenders \& Philip Jabre v Financial Services Authority (2006) 36 fin 06/2006, where the FSA successfully charged the accused persons for engaging in conduct that give rise to market abuse. Also see Rider, Alexander, Linklater \& Bazley Market Abuse and Insider Dealing 76-77; 206

40 In so doing it was stated that Marconi plc company had contravened Rule 9.2(c) of the FSA's Listing Rules.

${ }^{41}$ Additionally see the General Principle 3 of the FSA's Listing Requirements. Also see other civil cases that were successfully settled with the FSA's in table seven of Barnes Stock Market Efficiency, Insider Dealing 164-165 \& Rider, Alexander, Linklater \& Bazley Market Abuse and Insider Dealing 206-209.

42 See earlier related remarks above.

${ }^{43}$ See $s 84$ of the Financial Markets Act.

44 See earlier related remarks above.

45 See $s 84$ of the Financial Markets Act.

46 See related remarks above.

47 See s 84 read with s 82 of the Financial Markets Act.

48 See further related remarks by Chitimira \& Lawack "Overview of the Role-Players in the Investigation, Prevention and Enforcement of Market Abuse Provisions in South Africa" 2013 Obiter 200 200-217; Chitimira "Overview of Selected Role-Players in the Detection and Enforcement of Market Abuse Cases and Appeals in South Africa" 2014 Speculum Juris 108 108-124.

49 See related remarks above.

$50 \mathrm{~S} 84(2)(f)$ of the Financial Markets Act.

51 See related remarks above.

52 However, the FSB has to date issued several booklets and bulletins with general information regarding the regulation of market abuse practices in South Africa.
} 
regarding any suspected market abuse activity from the Johannesburg Stock Exchange Limited (the JSE). ${ }^{53}$ As indicated earlier, ${ }^{54}$ this is not the position in the UK where the FSA is authorised to appoint other additional skilled persons to provide it with reports or relevant information relating to any suspected market abuse violations. Nevertheless, like the $\mathrm{FSA}^{55}$ the FSB may impose disciplinary, administrative and civil sanctions like orders for compensatory and punitive damages as well as desist or cease orders on market abuse offenders. ${ }^{56}$

Notably, in order to enhance compliance and the general enforcement of market abuse prohibition in South Africa, the FSB has also purportedly entered into co-operation agreements with other international regulatory bodies like the FSA, the SEC and the IOSCO. ${ }^{57}$ However, it remains to be seen whether these co-operation agreements will be fully exploited by the FSB to combat cross-border market abuse activities in South Africa.

\subsection{The Role of the Courts}

The relevant courts and the DTI have played an important role in the enforcement of securities and market abuse laws in the UK. ${ }^{58}$ Put differently, the DTI ${ }^{59}$ and the courts initially had the main prerogative to prosecute all criminal cases involving market abuse in the UK. Thus, in spite of the fact that the FSA may now itself prosecute market abuse cases, it used to refer such criminal cases to the DTI and the courts for further investigations and/or prosecution. ${ }^{60}$ In most instances the DTI could prosecute and enforce securities violations that relate to general corporate matters, for example, the disqualification of directors. On the other hand, the courts may hear and prosecute any market abuse cases referred to them by the FSA.

In addition, it should be noted that the CPS is the public prosecuting body in England and Wales. The DPPs and the Crown Office are the bodies responsible for prosecuting market abuse cases in Northern Ireland and Scotland respectively. The courts have the power to investigate, prosecute and impose appropriate penalties on market abuse offenders. For example, the courts may impose civil, criminal and administrative sanctions on any person who indulges in market abuse activities. ${ }^{61}$ The courts may, on application of the FSA or any prejudiced person, further grant orders for judicial and quasi-judicial remedies such as injunction for restitution, freezing assets, declaratory relief, prohibitory and mandatory injunction relief as well as desist or seize orders against market abuse offenders. ${ }^{62}$ Undoubtedly, this has, in a way, further enhanced the FSA's imposition of administrative sanctions against the market abuse offenders in the UK. ${ }^{63}$ Additionally, the courts (including the Equity and Chancery Courts) may further award financial orders and damages to compensate all the persons affected by market abuse. 64

Despite the fact that some weaknesses and irregularities still exist in the criminal enforcement of the market abuse prohibition, the courts have to date successfully prosecuted a considerable number of cases involving market abuse in the UK. For example, cases like the Chase Manhattan Equities $v$ Goodman ${ }^{65}$ have been adequately prosecuted. In this case Knox $\mathrm{J}$ held that any transaction or dealing based on the misuse of inside information was against public policy, unenforceable and consequently resulted in criminal liability on the part of the offenders. ${ }^{66}$ Moreover, in the Scott $v$ Brown ${ }^{67}$ case, the Court of Appeal held that an agreement to stabilise the price of shares while a number of certain shares were brought into the financial market was illegal and unenforceable. This decision was inter alia probably intended at preventing market abuse practices like insider trading and market manipulation. In the Financial Services

\footnotetext{
${ }^{53}$ See related remarks by Chitimira \& Lawack 2013 Obiter 200-217; Chitimira 2014 Speculum Juris 108-124.

54 See related remarks above.

55 See related remarks above.

56 Generally see $s 82$ read with $s 84$ of the Financial Markets Act.

57 See generally related remarks by Chitimira \& Lawack 2013 Obiter 200-217.

58 Blair \& Walker Financial Services Law 299-300.

59 It is reported that the DTl's market abuse prosecutorial powers are now vested in the Department for Business Enterprise and Regulatory Reform (the DBERR). Herbert Smith "UK Market Abuse Update" 2009 Financial Regulation Briefing 1 2-3; see the DBERR's market abuse prosecutions on $<$ http://www.fsa.gov.uk/pages/Library/Communication/PR/2009/002.shtml> (accessed 28-01-2014).

60 S 402(1)(a) of the Financial Services and Markets Act.

61 S 381 of the Financial Services and Markets Act; also see s 148 of the Powers of Criminal Courts (Sentencing) Act 2000 (c 6), which empowers courts to impose restitution orders against all the convicted persons.

62 For further clarity check ss 129; 380; 381; 382 \& 383 read with s 348 of the Financial Services and Markets Act. Also see Russen Financial Services Authorisation, Supervision, and Enforcement: A Litigator's Guide (2006) 146-166.

${ }_{63}$ Significantly high penalties have further been, in many cases, successfully levied against individuals or companies that commit market abuse offences. See Rider, Alexander, Linklater \& Bazley Market Abuse and Insider Dealing 226-230.

64 This clearly suggest that the courts have a discretion to award equitable remedies like specific performance or rescission of Part IV permission against any person who violates market abuse provisions. S 50 of the Supreme Court Act 1981 (c 54). Also see Seager v Copydex (No 2) [1969] 1 WLR 809, where damages for misuse of price-sensitive (confidential) information were granted against the perpetrators of securities and market abuse violations; see further Rider, Alexander, Linklater \& Bazley Market Abuse and Insider Dealing 38-39.

65 [1991] BCLC 897.

${ }^{66}$ Also see related cases such as $R$ v Rigby, Bailey \& Rowley (2005) FSA/PN/106/2005 2005-10-07; R v Ghosh [1982] QB 1053 \& SIB v Pantell SA (No 2) [1993] BCLC 146 (CA). Generally see s 62(2) of the Criminal Justice Act; see further Rider, Alexander, Linklater \& Bazley Market Abuse and Insider Dealing 38-39.

${ }^{67}$ [1892] QB 724.
} 
Authority $v$ Fitt68 the High Court used its discretion to impose a freezing order against the persons accused of market abuse..$^{69}$

In a nutshell, the successful prosecution of the Guinness-Distillers, Blue Arrow, Geoffrey Collier and the Smith, Spearman and Payne scandals is clear evidence of the competence of the relevant courts to enforce the market abuse prohibition in the UK. For instance, in the Smith, Spearman and Payne case the defendants were found guilty of conspiracy to commit insider trading in January 2004 after Payne, who was a proof reader at a company of commercial printers, passed non-public information that he had seen at that company to the other defendants, involving drafts of the prospectus and offer documents prior to the announcement on the LSE. Eventually, about 27 takeover and merger transactions were made and all the defendants made almost $£ 336000$ profit. The Court of Appeal sentenced Smith and Catherine Spearman to 18 months imprisonment terms each. Payne was sentenced to 21 months in jail while Richard Spearman was imprisoned for 30 months.

Likewise, in the Financial Services Authority $v$ Martin and Anor, ${ }^{70}$ Alton $\mathrm{J}$ gave an injunctive relief against the defendants to cancel all the transactions that contravened some market abuse provisions. In some instances, the defendants were also ordered to compensate the affected investors directly for their incurred losses.

As indicated above, one can conclude that the effectiveness of the UK's market abuse regime is attributed to the competence of the relevant courts in enforcing and prosecuting market abuse cases. Accordingly, in spite of the inconsistent and relatively few successful criminal prosecutions recorded in market abuse cases by the courts during the DTI era, a notable increase in the number of successful prosecutions of such cases has been achieved since the FSA succeeded the DTI in 2001. ${ }^{71}$ In other words, although the DBERR and the FSA are empowered to prosecute market abuse cases, the relevant courts have to date consistently utilised their main prerogative to hear and prosecute all criminal cases involving market abuse violations in the UK.

In contrast to the position in the UK, ${ }^{72}$ it appears that apart from the FSB and the Enforcement Commitee (the EC), only the High Courts or Regional Courts have the jurisdiction to hear market abuse cases under the Financial Markets Act. ${ }^{73}$ Nevertheless, the high evidentiary burden employed in criminal cases of market abuse remains probably the main contributory factor of the paucity of convictions obtained in such cases in both the UK and South Africa. In line with this, it remains to be seen whether the Financial Markets Act's market abuse provisions will enhance the combating and prosecution of market abuse cases in South Africa. Additionally, unlike the position in the UK, ${ }^{74}$ it is not quite certain whether the relevant courts in South Africa may also rely on any skilled persons from the FSB itself or on persons who are assigned to them by the FSB to adjudicate in market abuse cases. Furthermore, the absence of sufficient persons with the relevant expertise to adjudicate in matters involving market abuse remains a significant challenge for the competent courts in South Africa. ${ }^{75}$

\subsection{The Role of Other Self-Regulatory Organisations}

In spite of the fact that the FSA was established as the main agency solely responsible for the enforcement of market abuse in the $\mathrm{UK}_{,}{ }^{76}$ several self-regulatory organisations (the SROs) have also made a significant contribution to the supervision and regulation of the securities and financial services industry in the UK to date. ${ }^{77}$

During the 1970s and the early 1980s, the SROs such as the Bank of England, the Personal Investment Authority, the Investment Management Regulatory Organisation, the Securities and Investments Board (the SIB) and the Securities and Futures Authority (the SFA) played a leading role in the prevention, investigation and prosecution of securities and market abuse cases in the UK. ${ }^{78}$ Nevertheless, serious systemic flaws were still evident in the regulation of the financial services industry in the UK. Therefore, in an attempt to rectify these flaws and to make the enforcement of the securities and market abuse laws more effective, most of the responsibilities of the Bank of England, the SIB and the SFA were transferred to the FSA in 1997.

\footnotetext{
${ }^{68}$ [2004] EWHC 1669 ch.

72 See related comments above.

${ }^{73}$ See $s 84$ read with ss $77 ; 78 ; 80 ; 81$ \& 82; also see Chitimira 2014 Speculum Juris 108-124.

${ }^{74}$ See related comments in paragraph 2.1 above.

75 See related analysis by Chitimira 2014 Speculum Juris 108-124

${ }^{76}$ See paragraph 2.1 above.

${ }_{77}$ Avgouleas The Mechanics and Regulation of Market Abuse 308-310.

${ }^{78}$ Avgouleas The Mechanics and Regulation of Market Abuse 309.
}

${ }^{69}$ This injunction or freezing order was generally awarded in accordance with s 381(3) \& (4) of the Financial Services and Markets Act.

70 [2005] 1 BCLC 495; also see R v Caldwell [1982] AC 341, where the court charged the accused for disseminating false and misleading information \& Bell $v$ Lever Brothers Ltd [1932] AC 161 where the defendant was sued for engaging in market manipulation practices that influenced the price of the affected securities.

71 See El Ajovu v Dollar Holdings [1993] 1 BCLC 760; Chaston v SWP Group Ltd [2003] 4 Current Law 78 \& the R v Rigby, Bailey \& Rowley FSA/PN/106/2005 2005-10-07 scandal which was criminally prosecuted on 18 August 2005; also see Rider, Alexander, Linklater \& Bazley Market Abuse and Insider Dealing 94. 
A number of regulatory organisations like the LSE, the London International Financial Futures and Options Exchange Administration and Management (the LIFFOEAM), the Serious Fraud Office (the SFO), the Financial Services and Markets Tribunal (the FSMT), the Financial Ombudsman Service (the FOS), the Financial Services Compensation Scheme (the FSCS), the DBERR, the RDC, and the Treasury are currently involved in the regulation and enforcement of market abuse in the UK.

The LSE is the main securities exchange in the UK which oversees the public trading of listed qualifying investments in the relevant financial markets to minimise and curb market abuse activities. This is done by adopting relevant rules and guidelines that restrict and discourage market abuse practices. The LSE further employs sophisticated and computerised surveillance systems to detect all possible market abuse activity. Where such activity is detected, a publication is made to the relevant financial markets and the FSA through the so-called Suspicious Transaction Reports to inform all the investors and possible investors. ${ }^{79}$

One of the Recognised Investment Exchange which plays a pivotal role in the regulation of market abuse is the LIFFOEAM. The LIFFOEAM has a mandate to investigate, operate and employ necessary measures that detect and discourage market abuse activities. For instance, it has powers to take disciplinary action like issuing private warnings to any person accused of serious misconduct or contravening market abuse provisions. ${ }^{80}$

The SFO was established under the Criminal Justice Act $1987^{81}$ and was granted wide investigatory and prosecutorial powers in respect of serious and complex corporate frauds. Consequently, since its introduction the SFO has investigated and prosecuted several cases involving insider trading and market manipulation. ${ }^{82}$ The SFO is further allowed to extract any information or documents necessary for an ongoing investigation from any accused persons. In addition, the SFO has the power to indict persons accused of fraud and/or market abuse offences and refer such matters to the CPS or the DPP for prosecution. 83

For the purposes of obtaining more settlements in cases involving securities violations, the FOS was introduced under the auspices of the Financial Services and Markets Act. ${ }^{84}$ The FOS was formally launched in December 2001 with the main aim of providing an independent alternative method of redress to all the affected persons or investors. In other words, the FOS is not a regulatory body per se; its main role is to resolve individual disputes between consumers (investors) and other market participants like financial services organisations. ${ }^{85}$ The FOS deals with all kinds of financial disputes involving securities violations. This could imply that the FOS may also deal with disputes involving market abuse violations. Moreover, the FOS administers the FSCS in instances where it has either compulsory or voluntary jurisdiction. ${ }^{86}$ The FSCS provides compensation to all eligible and successful complainants who were prejudiced by any securities violations. ${ }^{87}$

The FSMT is an independent regulatory body established to provide a platform for any person aggrieved by the decisions of the FSA to appeal. ${ }^{88}$ Consequently, the FSMT may hear any references or appeal against the FSA regarding its disciplinary decisions, cancellation of Part IV permission, imposed penalties, prohibition orders and its verdicts or final decisions on matters relating to market abuse. ${ }^{89}$ This is probably targeted at maintaining the stability and integrity in the UK's financial markets. However, it should be noted that the appeal against any FSA's decision must be made within 28 days of the date on which the decision notice or supervisory notice was issued. ${ }^{90}$ The FSMT may, if satisfied, conduct a de novo review of matters referred to it by authorised persons or by any other aggrieved persons. For purposes of providing appropriate redress to the affected persons, the FSMT is obliged to derive its rules or course of action in accordance with the provisions of the Financial Services and Markets Act. ${ }^{91}$ The FSMT may, for example, take decisions like re-hearing a matter, reviewing, dismissing an appeal or setting aside its own decision. ${ }^{92}$ Additionally, the FSMT may determine and give directions regarding the appropriate action to be followed by the FSA. ${ }^{93}$ The FSMT may further give

\footnotetext{
79 Barnes Stock Market Efficiency, Insider Dealing 199.

80 Swan Market Abuse Regulation 89.

81 (c 38); see $s 1$ of the Criminal Justice Act 1987.

${ }^{82}$ Avgouleas The Mechanics and Regulation of Market Abuse 383-387.

${ }^{83}$ S 401(2) of the Financial Services and Markets Act; also see Avgouleas The Mechanics and Regulation of Market Abuse 384; Kiernan "The Regulatory Bodies Fraud: Its Enforcement in the Twenty-First Century" 2003 The Company Lawyer 293293.

${ }^{84}$ S 225; also see Blair \& Walker Financial Services Law 166-183.

85 In contrast to the regulatory powers of the FSA which are usually invoked to seek redress on a more broad scale, the FOS is responsible for resolving disputes on an individual basis.

${ }^{86}$ Ss 226 \& 227 of the Financial Services and Markets Act; also see Blair \& Walker Financial Services Law 169-170.

${ }^{87}$ Russen Financial Services Authorisation, Supervision 340-346.

${ }^{88}$ See s 132 read with s 133 of the Financial Services and Markets Act. The FSMT is administered by the Tribunal Service, an executive organ of the Ministry of Justice in the UK Avgouleas The Mechanics and Regulation of Market Abuse 382-383.

89 S 127(4) read with s 133 of the Financial Services and Markets Act.

$90 S$ 133(1) of the Financial Services and Markets Act.

${ }^{91}$ Ss 133; 127 \& 388 of the Financial Services and Markets Act.

92 A person aggrieved by a decision of the FSMT is free to apply to a Court of Appeal for permission to appeal within fourteen days. See Rules 23 \& 24(5) of the FSMT.

${ }^{3}$ S 133(4); (5) \& (7) of the Financial Services and Markets Act.
} 
recommendations to the FSA regarding its rules and regulating procedures..$^{94}$

The Treasury has also played a crucial role in the general regulation of the securities and financial services industry in the UK. It is responsible for the overall institutional structure of the securities and financial services regulation and/or relevant legislation. As a result, the Treasury may take action in instances where serious securities law violations are reported to it. The Treasury can further appoint or remove members of the executive governing body and the nonexecutive committee of the FSA. Moreover, the Treasury can appoint an independent person to conduct a review and/or a separate independent inquiry into the efficiency or effectiveness of certain functions of the FSA ${ }^{95}$ and the specific circumstances regarding securities, market abuse or any other violations where such action is considered to be in the public interest. ${ }^{96}$

Another regulatory body which deserves some consideration is the RDC. The RDC was established as a committee of the FSA which exercises certain regulatory powers on behalf of the FSA. ${ }^{97}$ In spite of the fact that the chairman of the RDC is appointed by the FSA and that it is accountable for its decisions to the FSA, the RDC may conduct its own independent investigations and make its own decisions regarding market abuse violations. ${ }^{98}$ According to the Decision Making Manual of the FSA, the RDC is a separate regulatory body outside the FSA's management structure. ${ }^{99}$ In short, the RDC is also responsible for the enforcement, authorisation and supervision of the securities and market abuse laws in the UK. ${ }^{100}$

As indicated above, it is quite clear that SROs like the LSE, the LIFFOEAM, the SFO, the FSMT, the FOS and the RDC currently play an equally important role in preventing and curbing market abuse practices in the UK. These SROs may also take their own appropriate action regarding any market abuse violations. For example, the LSE has in most instances offered some relevant information to the FSA regarding its market abuse prosecutions. ${ }^{101}$ This culminated in the speedy settlement and prosecution of market abuse cases by the FSA. ${ }^{102}$ In addition, the FSA co-operates quite well with other international regulatory bodies like the IOSCO in order to combat cross-border market abuse practices in the prescribed financial markets in the UK. ${ }^{103}$

Additionally, in contrast with the position in the UK regarding the role of SROs, ${ }^{104}$ it appears as if the importance of the role of such organisations has to some extent been overlooked in South Africa. ${ }^{105}$ This may be reflected, in part, by the fact that only a few SROs, namely the JSE, the EC, the Directorate of Market Abuse (the DMA) and the Takeover Regulation Panel (the TRP), are either directly or indirectly involved in the enforcement of the securities and market abuse laws in South Africa. ${ }^{106}$ Nevertheless, apart from the FSB, there are no other SROs that are statutorily, specifically and mainly responsible for enforcing market abuse laws in South Africa. ${ }^{107}$ As a result, not many SROs have been actively involved in the enforcement of the market abuse prohibition to supplement the efforts of the FSB in South Africa to date. ${ }^{108}$ South Africa seems to have blindly adopted some of the enforcement methods that are employed in the UK by empowering the FSB as the only main regulatory board that oversees the enforcement of its market abuse ban. In relation to this, it is suggested that South Africa should consider practically implementing only the relevant principles of the UK's single regulator model because it is economical and less complex. This could increase the number of settlements and convictions in market abuse cases in South Africa. Additionally, it is not certain whether other SROs in South Africa have the same or similar statutory leverage available to the FSB to make their own decisions, rules and appropriate regulations in relation to market abuse offences. ${ }^{109}$ However, it is important to note that the DMA and the EC have functions ${ }^{110}$ almost similar to those of their UK counterparts, the RDC and the FSMT respectively. ${ }^{111}$

\footnotetext{
${ }^{94}$ See s 133(8) of the Financial Services and Markets Act; see further Rules 20 \& 21 of the FSMT. Also see generally Russen Financial Services Authorisation, Supervision $312-315$. ${ }^{95}$ Ss 12 \& 13 of the Financial Services and Markets Act.

${ }^{96}$ Blair \& Walker Financial Services Law 25-27.

${ }_{97}$ See Rider, Alexander, Linklater \& Bazley Market Abuse and Insider Dealing 209-210 \& Russen Financial Services Authorisation, Supervision 296-298. Also see s 395(2) of the Financial Services and Markets Act.

${ }_{98}$ Rider, Alexander, Linklater \& Bazley Market Abuse and Insider Dealing 210.

${ }_{99}$ See Chapter 4.2 of the Decision Making Manual which was inserted by the Enforcement (Settlement and Other Procedures) Instrument in October 2005.

100 See further Blair \& Walker Financial Services Law 146-148; Swan Market Abuse Regulation 106-107.

101 See related comments in paragraph 2.1 above.

102 See further related comments in paragraph 2.1 above.

${ }^{103}$ See similar comments above.

104 See similar comments above.

105 See related remarks by Chitimira \& Lawack 2013 Obiter 200-217; Chitimira 2014 Speculum Juris 108-124.

106 See related remarks on the role of each of these SROs by Chitimira \& Lawack 2013 Obiter 200-217; Chitimira 2014 Speculum Juris 108-124.

107 See Chapter X of the Financial Markets Act \& related remarks by Chitimira \& Lawack 2013 Obiter 200-217; Chitimira 2014 Speculum Juris $108-124$

108 See similar analysis by Chitimira \& Lawack 2013 Obiter 200-217; Chitimira 2014 Speculum Juris 108-124.

109 See Chapter X of the Financial Markets Act \& related remarks by Chitimira \& Lawack 2013 Obiter 200-217: Chitimira 2014 Speculum Juris 108-124.

110 See ss 85 \& 99 of the Financial Markets Act; ss 6A to 6I of the Financial Institutions (Protection of Funds) Act 28 of 2001 as amended, hereinafter referred to as the Protection of

Funds Act \& related remarks by Chitimira \& Lawack 2013 Obiter 200-217; Chitimira 2014 Speculum Juris 108-124.

111 See related remarks above.
} 


\section{Concluding Remarks}

As already pointed out, ${ }^{112}$ the UK employs an extensive regulatory approach which statutorily authorises only one regulator (the FSA) to oversee the enforcement of its securities and market abuse laws. Therefore, other the SROs may only exercise certain functions on behalf of the FSA in order to complement its enforcement efforts. ${ }^{113}$ The rationale for this single regulator model was, inter alia, to establish a more coherent and proportionate approach in relation to the regulation and enforcement of financial services, securities and market abuse laws as well as a level playing field for all investors and other relevant market participants in the UK. ${ }^{114}$ Thus, as pointed out earlier, ${ }^{115}$ the FSA has fairly managed to formulate high level objectives and measures, especially in relation to the enforcement of market abuse laws in order to obtain more settlements and prosecutions in market abuse cases. ${ }^{116}$

On the contrary, it was noted that South Africa has so far not been able to enforce its market abuse prohibition successfully and consistently in order to increase the combating of market abuse practices in its financial markets. ${ }^{117}$ The reason for this disparity could be that, unlike South Africa, the UK has devoted significantly more resources towards the enforcement of its securities and market abuse laws. ${ }^{118}$ In relation to this, it is suggested that the Financial Markets Act ${ }^{119}$ should be reviewed to enact provisions that specifically empower the FSB to appoint other additional skilled persons, apart from its own employees, to provide it with reports or relevant information relating to any suspected market abuse violations in South Africa. It was also suggested that South Africa should not have blindly adopted some of the enforcement methods that are employed in the UK without proper measures in place to ensure that such methods will be practically compatible and consistently enforced to combat market abuse activities in South Africa. ${ }^{120}$ Moreover, it was suggested that South Africa should consider practically implementing only the relevant principles of the UK's single regulator model because it is economical and less complex. ${ }^{121}$ It is further submitted, notwithstanding the possible constitutional-related conflicts and/or double jeopardy, that the Financial Markets Act should be amended to enact provisions that expressly empower other SROs in South Africa, apart from the FSB, to impose their own penalties or take any other appropriate action against any persons who indulge in market abuse activities in South Africa to increase deterrence.

It is also suggested, notwithstanding the challenges involving the availability of adequate resources, that more specialised market abuse courts manned by sufficient persons with the relevant expertise to adjudicate in matters involving market abuse should be established in all the provinces of South Africa to increase awareness and/or the combating of market abuse practices in the South African financial markets. It is further submitted that the FSB should be statutorily required to support the DPP and the relevant courts with the necessary information regarding ongoing market abuse cases in South Africa by assigning certain persons with the relevant expertise to assist the DPP and/or relevant courts in their prosecution of such cases in South Africa. Furthermore, the FSB should be statutorily required to provide its own Code of Market Abuse Conduct containing sufficient and adequate guidelines on factors that should be considered from time to time, in determining whether a trading practice and/or behaviour will give rise to or amounts to market abuse practices in order to increase the combating of such practices in South Africa.

In conclusion, it is hoped that the suggestions and/or proposals stated in this article will be carefully employed in the future to enhance the enforcement of the market abuse ban in South Africa.

\section{References}

Avgouleas E The Mechanics and Regulation of Market Abuse: A legal and Economic Analysis (Oxford University Press Oxford 2005) Barnes P Stock Market Efficiency, Insider Dealing and Market Abuse (Gower Publishing Limited Surrey England 2009)

Beuthin RC and Luiz SM Beuthin's Basic Company Law $3^{\text {rd }}$ ed (Butterworths Durban 2000)

Blair MQC \& Walker GA (eds) Financial Services Law 1 ${ }^{\text {st }}$ ed (Oxford University Press Oxford United Kingdom 2006)

Lyon GJ \& Du Plessis JJ The Law of Insider Trading in Australia (The Federation Press Sydney 2005)

Rider B, Alexander K, Linklater L \& Bazley S Market Abuse and Insider Dealing $2^{\text {nd }}$ ed (Tottel Publishing Haywards Heath 2009)

Russen J Financial Services Authorisation, Supervision, and Enforcement: A Litigator's Guide (Oxford University Press New York 2006)

\footnotetext{
112 See paragraph 2.1 above.

113 See paragraphs 2.3 above.

114 See generally Blair \& Walker Financial Services Law 53-55.

115 See paragraph 2.1 above.

116 See paragraph 2.1 above.

117 See related comparative analysis in paragraphs $2.1 ; 2.2$ \& 2.3 above.

118 See paragraph 2.1 above.

${ }^{119}$ See related comments in paragraph 2.1 above.

120 See related analysis in paragraph 2.3 above.

121 See related analysis in paragraph 2.3 above.
} 
Swan EJ Market Abuse Regulation 1st ed (Oxford University Press United States of America 2006)

\section{Journal articles}

Bhattacharya U \& Daouk H "The World Price of Insider Trading" 2002 Journal of Finance 75-108

Black J \& Nobles R "Personal Pensions Misselling: The Causes and Lessons of Regulatory Failure" 1998 MLR 789-820

Botha D "Control of Insider Trading in South Africa: A Comparative Analysis" 1991 SA Merc LJ 1-18

Botha D "Increased Maximum Fine for Insider Trading: A Realistic and Effective Deterrent?" 1990 SALJ 504-508

Cassim R "An Analysis of Market Manipulation under the Securities Services Act 36 of 2004 (Part 1)" 2008 SA Merc LJ 33-60

Cassim R "An Analysis of Market Manipulation under the Securities Services Act 36 of 2004 (Part 2)" 2008 SA Merc LJ 177-199

Cassim R "Some Aspects of Insider Trading - Has the Securities Services Act, 36 of 2004 Gone too Far?" 2007 SA Merc LJ 44-70

Chitimira H \& Lawack VA "Overview of the Role-Players in the Investigation, Prevention and Enforcement of Market Abuse Provisions in South Africa" 2013 Obiter 200-217

Chitimira H "Overview of Selected Role-Players in the Detection and Enforcement of Market Abuse Cases and Appeals in South Africa" 2014 Speculum Juris 108-124

Henning JJ \& Du Toit S "The Regulation of False Trading, Market Manipulation and Insider Trading" 2000 Journal for Juridical Science $155-165$

Jooste R "A critique of the insider trading provisions of the 2004 Securities Services Act" 2006 SALJ 437-460

Kiernan P "The Regulatory Bodies Fraud: Its Enforcement in the Twenty-First Century" 2003 The Company Lawyer 293-299

Luiz SM "Market Abuse and the Enforcement Committee" 2011 SA Merc LJ 151-172

Luiz SM "Insider Trading Regulation - If at First You Don't Succeed..." 1999 SA Merc LJ 136-151

Osode PC "The new South African Insider Trading Act: Sound law reform or legislative overkill?" 2000 Journal of African Law 239-263

Rider BAK "Policing the City-Combating Fraud and Other Abuses in the Corporate Securities Industry" 1988 Current Legal Problems 4768

Steinberg MI "Insider Trading Regulation-A Comparative Perspective" 2003 The International Lawyer 153-171

Van Deventer G "New watchdog for insider trading" 1999 FSB Bulletin 2-3

Van Deventer G "Harnassing Administrative Law in Encouraging Compliance" 2009 FSB Bulletin 3-4

\section{Case law}

\section{South Africa}

Pretorius and Another v Natal South Sea Investment Trust 19653 SA 410 (W)

United Kingdom

Bell v Lever Brothers Ltd [1932] AC 161

Chase Manhattan Equities v Goodman [1991] BCLC 897

Chaston v SWP Group Ltd [2003] 4 Current Law 78

El Ajovu v Dollar Holdings [1993] 1 BCLC 760

Financial Services Authority v Fitt [2004] EWHC 1669 ch

Financial Services Authority v Martin and Anor [2005] 1 BCLC 495

Financial Services Authority v (1) Sean Fradley (t/a Top Bet Placement Services) (2) Gary Woodward [2004] EWHC 3008 (Ch)

Philip Jabre v Financial Services Authority (2006) 36 fin 06/2006

$R$ v Caldwell [1982] AC 341

R v Ghosh [1982] QB 1053

R v Kylsant [1932] 1 KB 442

R v Rigby, Bailey \& Rowley (2005) FSA/PN/106/2005 2005-10-07

Scott v Brown [1892] QB 724

Seager v Copydex (No 2) [1969] 1 WLR 809

SIB v Pantell SA (No 2) [1993] BCLC 146 (CA)

\section{Legislation}

\section{South Africa}

Companies Act 61 of 1973

Companies Act 71 of 2008

Consumer Protection Act 68 of 2008 
Financial Institutions (Protection of Funds) Act 28 of 2001

Financial Markets Act 19 of 2012

Financial Markets Control Act 55 of 1989

Securities Services Act 36 of 2004

Stock Exchanges Control Act 1 of 1985

United Kingdom

Companies Act 1980 (c 22)

Companies Act 1985 (c 6)

Companies Act 2006 (c 46)

Company Securities (Insider Dealing) Act 1985 (c 8)

Criminal Justice Act 1993 (c 36)

Criminal Justice Act 1987 (c 38)

Financial Services and Markets Act 2000 (c 8)

Financial Services Act 1986 (c 60)

Fraud Act 2006 (c 35)

Larceny Act 1861 (24 and 25 Vict c 96)

Powers of Criminal Courts (Sentencing) Act 2000 (c 6)

Prevention of Fraud (Investments) Act 1939 (c 16)

Prevention of Fraud (Investments) Act 1958 (c 45)

Supreme Court Act 1981 (c 54)

\section{European Union}

Commission Directive 2003/124/EC of 22 December 2003 implementing Directive 2003/6/EC of 28 January 2003 on the definition and public disclosure of inside information and the definition of market manipulation [2003] OJ L339/70

Commission Directive 2003/125/EC of 22 December 2003 on the fair presentation of investment recommendations and the disclosure of conflicts of interest [2003] OJ L339/073

European Union Directive on Insider Dealing and Market Manipulation, the Directive of the European Parliament and Council of 28 January 2003 on insider dealing and market manipulation (market abuse) 2003/6/EC [2003] OJ L96/16

European Union Insider Dealing Directive, Council Directive 89/592/EEC of 13 November 1989 [1989] OJ 1989 L334/30

\section{Commissions, Committees, Statutory Instruments and Reports}

\section{South Africa}

Financial Services Board Annual Report 2011

Financial Services Board Annual Report 2013

The King Task Group into Insider Trading Legislation Minority Report on Insider Trading 1997

The King Task Group into the Insider Trading Legislation First Report 15 May 1997

The King Task Group into the Insider Trading Legislation Final Report 21 October 1997

Van Wyk de Vries Commission of Inquiry into the Companies Act of 1973

\section{United Kingdom}

Enforcement (Settlement and Other Procedures) Instrument's Decision Making Manual October 2005

Financial Services and Markets Act 2000 (Market Abuse) Regulations 2005 SI 2005/381

Financial Services and Markets Act 2000 (Prescribed Markets and Qualifying Investments) Order 2001, SI 2001/1996 as amended by Regulation 10 of the Market Abuse Regulations 2005

Financial Services Authority Handbook (Code of Market Conduct) FSA Release 19 July 2001

Financial Services Authority's Market Abuse Directive Disclosure Rules Instrument 2005, 17 March 2005

Financial Services Authority's Market Abuse Directive Instrument 2005, 17 March 2005

Insider Dealing (Securities and Regulated Markets) Order 1994

Traded Securities (Disclosure) Regulation 1994

United States of America

Commodity Futures Trading Commission \& the United States Securities and Exchange Commission "A Joint Report of the SEC and the 
CFTC on Harmonization of Regulation" Report 16 October 2009

International Organisation of Securities Commissions Technical Committee Working Party 4 on Principles for Memorandum of Understanding, XVI Annual Conference 5 September 1991

\section{Thesis and Dissertations}

Chitimira H A Comparative Analysis of the Enforcement of Market Abuse Provisions (LLD-thesis Nelson Mandela Metropolitan University 2012)

Chitimira H The Regulation of Insider Trading in South Africa: A Roadmap for an Effective, Competitive and Adequate Regulatory Statutory Framework (LLM-dissertation University of Fort Hare 2008)

\section{Media Releases and other Relevant Material}

Herbert Smith "UK Market Abuse Update" 2009 Financial Regulation Briefing 1

\section{Newspaper Reports}

Chanetsa B "Insider Trading is Notoriously Hard to Prosecute" Business Report 26 April 2004

\section{Internet Sources}

Barron C "Greg Draws a Blank in Belfort Parallel" (2014) <http://www.timeslive.co.za/Feeds/2014/02/02/greg-draws-a-blank-in-belfortparallel> (accessed 03-03-2014)

Blincoe R "Datatec Directors Pay Up on Insider Trading Charges" (2001) <http://www.theregister.c0.uk/2001/05/23/ datatec_directors_pay_up/> (accessed 03-03-2014)

Commodity Futures Trading Commission \& the Financial Services Authority FSA's Memorandum of Understanding on Consultation, Cooperation and the Exchange of Information Related to Market Oversight (2006) <http://www.fsa.gov.uk/pubs/mou/cftc.pd> (accessed 27-01-2014)

Financial Services Authority "FSA Signs Regulatory Cooperation Agreement with the CFTC" (20-11-2006) http://www.fsa.gov.uk/pages/ Library/Communication/PR/2006/118.shtml> (accessed 27-01-2014)

Financial Services Board "Enforcement Committee Actions" Media Release (28-06-2011) <http://www.fsb.co.za/ftp://ftp.fsb.co.za/public/ documents/AReport2011.pdf> (accessed 22-11-2013)

Financial Services Board "List of Current Investigations of the Directorate of Market Abuse" Media Release (28-06-2011) <http://www.fsb.co.za/ftp://ftp.fsb.co.za/public/documents/AReport2011.pdf> (accessed 22-11-2013)

Johannesburg Stock Exchange Limited "Insider Trading and other Market Abuses (Including the Effective Management of PriceSensitive Information)" in the Insider Trading Booklet, (2013) <http://www.jse.co.za/Libraries/JSE_Regulatory_ Environment_Insider_Trading/InsiderTrading_Booklet.sflb.ashx> (accessed 03-03-2014)

Loubser "Insider Trading and other Market Abuses (Including the Effective Management of Price-sensitive Information)" in the Insider Trading Booklet final draft, (2006) <http://www.jse.co.za/public/insider/JSEbooklet.pdf> (accessed 03-03-2014)

Myburgh A \& Davis B "The Impact of South Africa's Insider Trading Regime: A Report for the Financial Services Board" (25-03-2004) <http://www.genesis-analytics.com/public/FSBReport.pdf> (accessed 09-02-2013)

Van Deventer G "Anti-Market Abuse Legislation in South Africa" (10-06-2008) <http://www.fsb.co.za/public/marketabuse/FSBReport.pdf> (accessed 05-05-2013) 